Mahsa Kazempour. (2014). The Interrelationship of Science Experiences, Beliefs, Attitudes, and Self-Efficacy. Journal of Education and Learning. Vol.8 (1) pp. 51-64.

\title{
The Interrelationship of Science Experiences, Beliefs, Attitudes, and Self-Efficacy: A Case Study of a Pre-Service Teacher with Positive Science Attitude and High Science Teaching Self-Efficacy
}

\author{
Mahsa Kazempour ${ }^{*}$ \\ Penn State University-Berks Campus, United States
}

\begin{abstract}
This qualitative case study aimed to focus on the experiences and subsequent science and science teaching beliefs, attitudes, and self-efficacy of an elementary pre-service teacher, Heather, with extremely positive attitude and high self-efficacy. For this particular population of pre-service teachers, possessing a high science teaching self-efficacy alone is not sufficient to assume reform-based beliefs and teaching practices. This study was unique in that it concurrently explored the relationship between attitude, beliefs, and self-efficacy before and after the course. Initially, Heather's attitude and self-efficacy with respect to science and science teaching were closely interrelated and a product of her own intrinsic interest in science and her unique K-12 experiences. Her beliefs appeared to have been shaped by both her actual science experiences and what she had witnessed in the classrooms. Heather's course experiences shaped her post beliefs about science and science teaching, which consequently altered her attitude and confidence.
\end{abstract}

Keywords: Teacher Education, Science Education, Beliefs, Self-Efficacy, Attitude, Pre-Service Teachers

\footnotetext{
* Mahsa Kazempour, Science Education, Penn State University-Berks Campus, United States email: muk30@psu.edu
} 


\section{Introduction}

Inquiry has been at the heart of science education reform initiatives (NRC, 1996; 2012; NSTA, 2002) and research during the past several decades. Engaging students in scientific inquiry practices, which include a number of "social, epistemic, and cognitive" tasks (Duschl, 2008), such as posing and refining questions, making observations, discussing data, and writing about data (Grandy \& Duschl, 2007), is grounds for developing a scientific literate student population. Inquiry-based learning is advocated for the continuum of K-16 science education, with special emphasis on the elementary grades, which serve as the foundation for strong secondary and post-secondary science education (NRC, 1996; NSTA, 2002). Early science experiences have been identified as critical for the development of learners' scientific knowledge, skills, beliefs, and attitudes that will carry on into their adult life as citizens in an increasingly science and technology dependent world (King, Shumow, \& Lietz, 2001).

Yet, we continue to witness that in the elementary grades science is either absent, receives limited attention, or is taught using approaches not aligned with reform efforts (Appleton \& Kindt, 2002; Fulp, 2002; Weiss, Banilower, McMahon \& Smith, 2001). This begs the question: why have reform efforts and continuous research focused on enhancing science teaching practices, and therefore learners' science experiences, not been successful in enhancing the quantity and, perhaps more importantly, the quality of science education, in particular at the elementary level? The response to this question is multifaceted; however, it has been argued that this phenomenon has been due, in part, to reform efforts' lack of recognition that "instructional practices are influenced by a complex set of belief systems, prior knowledge, epistemologies, attitude, knowledge, and skills" and have "failed to conceptualize reform as situated within this complex system” (Jones \& Carter, 2007, p. 1087). Focusing on teachers' cognitive and affective features will be essential in producing long lasting positive change in science education.

Furthermore, although research on the impact of teacher professional development, at the preand in-service levels, certainly exist, they focus on overall pictures of change rather than directing attention to specific individual teachers' personal shifts in beliefs, attitude, and sense of comfort with science (Author, in review; Loughran, 2007). This study aims to focus on the experiences and subsequent science and science teaching beliefs, attitudes, and self-efficacy of an elementary preservice teacher (PST) with extremely positive attitude and high self-efficacy. In particular, I was interested in exploring possible (a) reasons for the initial high self-efficacy and positive attitude, (b) impact of her prior sciences experiences on her initial epistemological beliefs, (c) relationships between the three constructs (both before and after the course), and (d) changes in the three domains, if any, experienced as a result of the course.

\section{Theoretical Framework}

Reform documents such as the National Science Education Standards (1996) or the most recent A Framework for K-12 Science Education (NRC, 2012) call for inquiry-based teaching in the classrooms where students are involved in scientific practices such as posing questions, exploring ideas, making observations and collecting data, communicating data, and formulating ideas based on their data. There is an emphasis on students' active engagement in their learning, exploration of concepts, developing science skills, and applying their knowledge (NSTA, 2002). Consequently, the reforms have also concurrently focused on teachers who are seen as the key to the success of reforms. Elementary teachers' role in impacting young students' scientific knowledge and attitude toward the subject is undisputable (Rennie, Goodrum, \& Hacking, 2001), so it is critical to examine the underlying factors shaping their teaching practices.

The Sociocultural Model of Embedded Belief Systems, developed by Jones \& Carter (2007), serves "as a basis for framing recent research on science teacher attitudes and beliefs and as a tool for understanding the construction and development of beliefs and attitudes" (p.1074). The model suggests that teachers' epistemological beliefs (beliefs about science, students, and science teaching and learning), attitude toward, and sense of self-efficacy with regard to science and science teaching together influence and are in turn shaped by teachers' instructional practices. Teachers' epistemological beliefs, which have been shaped by their prior formal and informal science experiences (Appleton, 2006), consequently influence their teaching practices and may serve as an impediment to the implementation of reform-based curricula (Brickhouse, 1990; Munby et al., 2000; Tobin \& McRobbie, 1996;). Hence, it is imperative for teacher educators to consider PSTs' prior educational beliefs and experiences and adapt their teaching to facilitate PSTs' experiences.

Similarly, teachers' attitudes toward science have been shown to affect their teaching practices (Siegel \& Ranney, 2003). Consequently, students' learning experiences, attitude toward science, and achievement in science, are all impacted by teachers' instructional practices, beliefs, as well as attitudes 
(positive or negative) toward science and teaching science (Bittner \& Pajares, 2006; Simpson \& Oliver, 1990). Elementary teachers' negative science attitudes have been attributed mainly to their prior K-12 science experiences (Appleton, 2006; Mullholland \& Wallace, 1996). Their negative past experiences with science, and subsequent negative attitude toward science and science teaching may serve as a major obstacle in their teaching of science or doing so effectively.

Finally, teachers' science self-efficacy, which is interchangeably referred to in the literature as confidence or comfort with science and science teaching, simply relates to the belief that one has the ability to effectively teach science and that their students can indeed learn science (Ramey-Gassert, Shroyer, \& Staver, 1996). Prior research have indicated that teachers with low perceived science teaching self-efficacy do not feel comfortable about their ability to practice or teach science and find little interest in doing so. Therefore, they may resort to avoiding science or do so utilizing ineffective approaches that are contradictory to the reforms. Conversely, teachers with high self-efficacy, have been shown to be more inclined to teach science and apply reform-based strategies in the classroom (Avery \& Meyer, 2012; Hechter, 2011).

Teacher education reform movements have focused on improving PST education in an effort to instigate changes in elementary teachers' cognitive and affective domains and consequently their instructional practices (Supovitz \& Turner, 2000). Instigating changes in teaching practices in the elementary grades entails a radical shift in elementary teachers' attitudes, beliefs, and confidence that should be a central focus of PST professional development (Haney, Czerniak, Lumpe, 1996; Moore, 2008). A review of prior research indicates that teacher education programs, particularly the science methods courses, have the potential to lead to appropriate beliefs, increased confidence levels, and positive attitude with regard to science and science teaching (Avery \& Meyer, 2012; Bleicher \& Lindgren, 2005; Morrell \& Caroll, 2003), which in turn, have been shown to lead to more effective and reform-based instructional practices (Moore, 2008).

The research on these three domains has been predominantly focused on secondary teachers or in-service elementary teachers (e.g. Beck, Czerniak, \& Lumpe, 2000; King et al., 2001; Luft, 2001; Simmons et al., 1999; Tobin \& McRobbie, 1996). Studies on elementary PSTs are far fewer. Those focusing on elementary PSTs' beliefs tend to be descriptions of their existing beliefs, rather than factors that have shaped their beliefs, changes they may experience during science methods or other teacher education components, or the relationship of their beliefs (pre or post) with the two constructs of attitude and self-efficacy. The studies dealing with PSTs' attitude and self-efficacy utilize quantitative methods and instruments to measure current trends or pre-post changes within whole classes or programs, without focusing on individuals, and exploring personal shifts in their attitudes and selfefficacy. Furthermore, as evident in the previous sections, studies examining the interrelationship between the three constructs are not readily available. Instead, most studies focus on the constructs independently or examine the relationship between two constructs (e.g. beliefs and attitude or beliefs and self-efficacy).

Finally, the literature mainly alludes to the low self-efficacy and negative attitudes of elementary PSTs, but it is also necessary to focus research effort into understanding PSTs who enter teacher education programs with positive attitude and high self-efficacy with regard to science and science teaching. In so doing, key questions with regard to this population could be explored in order to better recognize the underlying dynamics that may serve as lessons for K-12, as well as, post secondary science and teacher education. For instance, are this group's initial positive attitudes and elevated sense of comfort with science due to their prior science education experiences or are there other factors involved? Prior research indicates that teachers with high self-efficacy tend to have beliefs that are more aligned with reforms, but to what extent could this be assumed about PSTs who have not yet completed teacher education programs? What, if any, impact, could a reform-based science methods course have on their beliefs and even their attitude and self-efficacy? And what is the relationship between the three constructs of beliefs, attitude, and self-efficacy both before and after the completion of such a course? The current case study attempts to address these questions.

\section{Methodology}

This case study is part of a larger multi-case study that took place in a science methods course for elementary education majors at a large Midwestern university. It focuses specifically on one case, a PST who entered the course with high self-efficacy and positive attitude toward science and science teaching. The participant was purposefully selected based on her scores on the Science Teaching Efficacy Beliefs Instrument for PSTs, STEBI-B (Bleicher, 2004; Enochs \& Riggs, 1990) and the Revised Science Attitude Scale for PSTs (Bittner, 1994; Thompson \& Shrigley, 1986) that were administered during the first class session as well as initial qualitative data sources described in the data collection section. A case study approach was considered most appropriate in exploring (a) possible 
reasons for this PST's initial high self-efficacy and positive attitude, (b) possible impact of her prior sciences experiences on her initial epistemological beliefs, (c) possible relationship between the three constructs, and (d) changes in the three domains, if any, experienced as a result of the course. A case study approach allowed for rich, in-depth analysis of the aforementioned items through focusing mainly on the participant's reflections, interview statements, and other artifacts (Keeves, 1998).

\section{Course Context}

The case study participant was part of a cohort of elementary PSTs simultaneously enrolled in science methods, mathematics methods, and field observation experience and seminar. Prior to enrolling in the science methods course, students, a majority of whom were second or third year students, were required to enroll in an introductory science content course. Depending on where they were in the program, students may have had already taken or were concurrently enrolled in one or two additional science content courses required for the completion of the program. The science methods course was taught based on the social constructivist perspective. PSTs were immersed in inquiry-based learning and discussions that enabled them to reflect on their prior experiences and beliefs and individually and collaboratively construct a new understanding of science and science teaching.

\section{Data Collection and Analysis}

A series of data sources was analyzed to develop an in-depth understanding of the participant and explore patterns and themes within the data. The two quantitative instruments served dual purposes: to initially identify the case and gauge changes in her attitude and self-efficacy by the end of the course. The qualitative data included (a) student artifacts such as bi-weekly reflections, pre/post science autobiography, and pre/post drawings and descriptions of scientists and science classrooms, (b) pre/post semi-structured interviews to further probe their initial and post experiences, beliefs, attitudes, and selfefficacy and the interrelationship between them, and (c) videotaped course observations and daily logs.

The various data sources were simultaneously analyzed using the constant comparative method (Glaser \& Strauss, 1967) to identify recurrent patterns and emerging themes within the data (Bogden \& Biklen, 1992) and resulted in a rich description of the case. An outside reviewer was asked to review portions of the data and corroborate the emerging themes. Finally, the full analysis of the data was followed with member checking by the participant to ensure an accurate portrayal of her experiences and affective and cognitive features.

\section{Heather's Path to Teaching}

\section{Results \& Discussions}

Heather was a senior in the elementary education program who was set to graduate the semester following the elementary science methods course. Her area of concentration within the program was health and science. During her first two years at the university she had majored in biology as a pre-Med student and made the decision to transfer to the elementary education program during her third year. Prior to enrolling in the elementary science methods course she had enrolled in the physics and biology course required for elementary education majors as well as six biology and chemistry courses she had completed during here first two years.

Contrary to her peers in the course, Heather had not have any desire to become a teacher early in life. Because of her high interest in science, she had always thought about becoming a doctor, but during the third year in college her plans began to change as she became increasingly interested in teaching as a result of her involvement in a series of summer and after schools programs that enabled her to have increased interactions with children. She initially considered teaching high school biology, especially AP biology, considering her strong science background; however, her participation in the youth soccer camp convinced her to pursue teaching younger students at the elementary level so that she could "work with children and help them with gaining skills and knowledge and encourage them to pursue their own dreams.” Her preference was to work with K-3 grade levels, particularly second graders whom she had worked with in camp. The only perceived disadvantage to teaching this grade, she explained, would be "their science ability." For example, she discussed how she "loved to teach her students about biological topics such as plants and animals," but felt that "it would be difficult to do at this age." Instead she felt she could concentrate on "guiding their interest in science which will be a great tradeoff."

\section{Heather's Prior Science Experiences, Attitude, and Self-Efficacy}

Table 1 summarizes Heather's initial scores on the attitude toward science instrument, which were the highest in the class. 


\begin{tabular}{lc} 
& $\begin{array}{c}\text { Heather's } \\
\text { Scores }\end{array}$ \\
\hline Revised Attitude Toward Science Scale: Total Score & Class Average \\
Revised Attitude Toward Science Scale: Mean Score & \\
Self-rating of interest toward science (1-5 scale) \\
STEBI-B Total Score \\
STEBI-B Mean Score \\
Self-rating of confidence: science (1-5 scale) \\
Self-rating of confidence: science teaching (1-5 scale)
\end{tabular}

Heather's early reflection assignment and interview suggested that her interest in science and "passion and fascination with making discoveries about the world" had blossomed beginning early in her childhood, prior to entering a formal school setting and persisted into her adulthood.

As a child I was always outside messing around in the dirt. I liked to catch bugs and put them in a jar and watch them interacting with other insects. I now know that I was studying them and observing their characteristics. This fascination continued when I started school and has not let up yet.

She described her past experiences with science as positive: "I have always felt the ability and desire to try new things with science and experiment the outcomes of thoughts or ideas I have had." Her interest in learning and being involved in science appeared to have been intrinsic in nature rather than shaped by her K-12 science education experience or other external factors. Conversely, Heather actually explained that because her attitude toward science was positive to begin with, she enjoyed school science regardless of the circumstances or the type of instruction. She excelled in her grade school and high school science courses, including honors chemistry, honors biology, and AP biology, but made no mention of classroom instructional approaches or teacher attributes that contributed to her success in these classes. Instead, she discussed how her rural school teachers' willingness to allow her to do independent research and pursue her own questions, rather than following the class activities that she found little or no interest in, had further enabled her success, positive attitude, and sense of confidence.

My elementary science experience didn’t influence my interest. Up until high school I was forced into the science classes I didn’t want to take. I never really learned what the teacher told me to learn to be honest with you. I went in my own direction and looked up whatever I wanted to. Below is her description of her independent science experiences during the elementary grades.

I grew up loving nature and being outdoors. When I got into grade school I found the human body to be so interesting I could not learn enough about it. I also remember the first time I learned about cells and we were making cell models. I made a tall cake and cut out a piece, showing the inside of the cake/cell. She also discussed her involvement with science fair projects all through grade school and high school and her excitement about such projects.

I made a telegraph one year and taught Morse Code with it to my peers. I also did a demonstration with liquid nitrogen. I froze a banana and later ate it showing the effects of liquid nitrogen. I really enjoyed doing these projects. She provided an example of independent research she embarked upon during her high school honors biology course and how that, along with other similar experiences, provided further boost in her sense of confidence and attitude toward science.

We were dissecting cats when I found a mass in the abdomen. I was curious so I took a biopsy and looked at it under the microscope to determine how the cells had formed. It looked like nothing I had ever seen before and I was able to determine that it was a tumor originating off the liver. I was really proud that I was able to determine that information and it was then that I officially thought of myself as a successful science student.

Heather had felt comfortable asking science related questions and seeking answers to these questions through independent research and experimentation. She indicated that she always felt "that science came easy" to her and was confident in her abilities to understand scientific concepts and be active in research. The fun and success she had with experiences, such as with the dissection example above, allowed her to view herself as a successful science learner. Heather's interest and success in science learning continued onto college where she enrolled in a series of science courses as a science major and enjoyed all of her experiences. She rated her interest and confidence toward science the highest rating of ten and explained "science has always been my favorite subject because I have fun doing experiments and finding out information and I am quite capable of doing so.” 
Her attitude and confidence toward teaching science, as reflected by the scores on the quantitative instruments and her own self-ratings, were also remarkably far above the class average and the highest among the group. Even as she abandoned the idea of pursuing science as a career, her positive attitude toward learning science continued to shape her interest in teaching science. She expressed a desire to pass on her passion for science to "young students so that they would also find excitement in this subject." She described how her interest and strong sense of ability with respect to science made it her favorite subject to teach.

I have decided I want to get children as excited about science as I was. I hope by doing this they will fall in love with something they have never experienced before. I have not really taught anything before but I would assume that my favorite will be science just like my personal learning preferences. I like to teach science best because I know more about it than any other subject. I feel confident about the subject matter and feel like I might be someone who can help a child learn to love science. Heather explained that although due to her lack of prior teaching experience, she felt unprepared at that moment to teach elementary students, she felt she could "easily teach science with a little preparation and given a curriculum to teach from because I know a lot about science and have done it so much.”

\section{Heather's Initial Epistemological Beliefs}

The analysis of the data pertaining to Heather's beliefs about science and science teaching, revealed interesting findings and insight about her epistemological beliefs and the role of her prior science experiences in shaping her beliefs.

\section{Beliefs about science}

Heather described science as "the study of all living matter and learning the explanation to everything that surrounds us. While it is a broad definition the word is hard to narrow down to specifics." Her concentration on living organisms may have simply been due to her own interest and prior pursuit of biology as a major and career path. In her drawing of a scientist, she depicted a woman wearing a lab coat and dark glasses with a ponytail, who was holding a magnifying glass and observing something on the table. She added that scientists do their work by "laying out a plan of action" and "testing various questions." She highlighted the importance of making predictions and using "a trial and error method in order to make conclusions about a question.” She also stressed the empirical nature of science, "science is based on observation and empirical evidence and the testability of scientific questions." Finally she added that conclusions made in science must also be based on "provable concepts."

Surprisingly when asked to compare school science with science as practiced by scientists, Heather referred to school science as what she normally witnessed in classrooms throughout her K-12 education, rather than what she herself was involved with in terms of independent research. She felt there was a definite difference between the two types of sciences. Scientists, she argued, use available information to produce new information that is then taught in classroom science. She viewed classroom science as children "learning through the textbook information that has already been discovered" and felt that it was necessary for "children to learn the basics of science before they can do any testing of their own." She described an element of "teaching" the concepts, and students "learning the basis of science" before they can "confirm what is being taught and what scientists have discovered."

She argued that school science in its reliance on textbook and direct didactic teaching is similar to other school subjects. Its distinction from other subjects, she explained, lies in the occasional "handson" nature of school science. She also alluded to the "changing nature of science, which sets it different from other school subjects, such as history, which usually remain unchanged.” Finally, she explained that science depends on a set process, "the scientific method", which she explained contains components, such as "the use of performing experiments to test a theory or a hypothesis one has about something," that are absent in other subjects.

\section{Beliefs about teaching and learning}

In her initial drawing of a science classroom, Heather depicted a teacher in the front of the class and next to a desk with a board behind it with the words "Science Experiment" inscribed on it. There were also five tables of four arranged in one row across the class. She described the picture in this way:

I am teaching students new material and allowing them to do an experiment to learn more about the material. I believe children need to work in groups and learn from one another in order to make school fun and interesting for them and to learn the necessary content. Heather's beliefs about teaching and learning, as reflected in this task and other data, revolved around two central ideas: focus 
on content mastery and increasing students' interest in science. She reflected on her own childhood experiences and expressed a yearning to pass on her desire for learning science and overall interest in school to her students. She stressed the importance of encouraging students to "become more interested in science and not fear the subject." She wanted to be able to express some of her own interest for science and enable the students to learn science concepts while also having fun and enjoying their experiences, "because I know kids are really interested and then it kind of dies down." To maximize student interest and confidence in science she focused on the classroom environment and making it comfortable and fun, mainly through what she referred to as a "hands-on approach."

In doing so, she wanted students to be involved in the process of science, enjoy it, and embark on further science learning. Heather had been allowed to research and explore topics that were of interest to her during her K-12 education and she felt that this would be an effective means of encouraging more students to do science and learn the content.

Children learn science by making hypothesis and exploring things. They learn by touching things, taking them apart and exploring the possible reasons why it would work the way it does. Therefore, I want my children to learn science through doing. She further explained, "science is not always thought of as being as important subject, so I plan on using many different activities to help students understand the material. I am a strong believer of learning science through demonstrations and hands-on learning.

However, on numerous occasions, Heather suggested conflicting comments about her idea of fun and hands-on teaching. She made it clear that these investigations and hands-on learning activities would be more "teacher directed" with the teacher having a central and dominating role in the classroom. The hands-on activities were meant to be an added component to simply make the "learning environment positive and fun" for the students. The teacher's role would be to direct the learning process by teaching the content and then "preparing the students" for the hands-on experiences.

I would hope to give my students all they need to test their scientific theories and experiment until they find the results and draw accurate conclusions. I would show examples and to help the children understand what they're looking for and just keep giving them hints and keep them interested and keep going further.

In discussing her beliefs about teaching and learning, Heather seemed to simultaneously draw upon both the traditional classrooms she had witnessed and the independent research and activities she had herself been involved with. Her beliefs were a mixture of the two experiences. She had elements of the traditional classroom with the teacher directing students' learning and providing all the necessary content and procedures and the students simply passively learning. The hands-on element, which she had personally experienced on several occasions, was simply a way to make students' learning more fun and meaningful even though it was merely done to confirm the content material "taught by the teacher or read in the book.” In looking more closely at her descriptions of her own prior experiences, it seems that even some of those may have been independent research that had involved "searching in books and asking adults," and doing step by step science investigations as in some of her science fair experiences.

Heather's beliefs about hands-on learning in a teacher-centered classroom were also reflected in her continuous focus on content mastery. She placed great emphasis on students "mastering the appropriate content material and curriculum for each grade level in order to be able to proceed to the next grade level." She also emphasized preparing students to be able to "apply their learning to real life problems and develop appropriate reasoning skills." She explained that the teacher's role was to ensure students would learn the necessary content by "teaching them the basics of science," "doing demonstrations," and allowing students to do experiments to enhance their learning of the subject.

\section{Heather's Post Epistemological Beliefs, Attitude, and Self-Efficacy}

The analysis of the post data indicated changes in Heather's beliefs, attitude, and self-efficacy and alluded to interrelationships among her course experiences and these domains.

\section{Beliefs about Science}

Heather's definition of science became more specific at the end of the semester. She described science as "constant questioning and a way of life" and explained, "science is everywhere, in the book you're reading, the computer you're using, the soda you just drank, and the oxygen you need for survival.” She utilized her own personal interest for life sciences and the study of living organism as an example to illustrate how science is about curiosity and questioning about the world around us.

I find the most interesting topic in science to be living organisms. When I hear about something occurring in the world I often think about what is happening to the environment around it. That may seem to be a bit nerdy however, every organism from the one-cell organism to humans fascinate me. In my opinion if you are a person who loves science you are always questioning what is 
occurring around you. Her post scientist drawing also supported this view. She explained that her drawing of a female figure with no glasses or lab coat was meant to show "that anyone can be a scientist, even me!" She also depicted an outside nature scene, rather than a laboratory, where the scientist seemed to be using a magnifying glass to observe something in the grass. She indicated that the course had helped her realize that "science is more about inquiry rather than hands-on activities."

\section{Beliefs about Teaching and Learning}

Changes that had occurred with respect to Heather's beliefs about science had in turn influenced her beliefs about teaching and learning science. Because she now understood the centrality of inquiry in scientific work, she had also shifted to thinking that learning science should move beyond simple hands-on learning and involve scientific processes and practices.

I have always considered science to be a hands-on learning process. However, being in this class has showed me that there is much more to science than taking part in hands-on activities. This class has showed me that science involves thinking, predicting, inferring, applying, explaining, and elaborating, all along with hands-on activities.

Consequently, she only viewed school science and science as practiced by scientists different only in terms of the scale and scope of their practice. She explained that if students are engaged in inquiry science learning, they are involved in the same processes as scientists.

We witnessed a great example of this in the video we watched with the male teacher working with his students. They were acting like mini-scientists in conducting their unit about plants and growing them in the classroom. They took an inquiry-based approach in acting like scientists. They developed questions and predictions, tested their theories, made observations, and explained their findings. This is much like what a scientist does when working on solving a problem or explaining a phenomenon.

She then explained that the way science is sometimes taught in schools and the way she experienced it in her own K-12 education, are limited and do not fully and accurately reflect science, because while they allow for testing and research, it is only to confirm an existing knowledge. This is in reference to her own experiences of sometimes doing independent work that simply involved searching the literature or doing hands-on experiments using set procedures.

I think that while school students are testing and researching things that scientists have already tested and found the answer to, students are doing this science to reinforce what is already known. While this may not always be the case it has been true for my science experience. For instance, I created aspirin in chemistry one year, but I was only able to synthesize this material because I had researched how to make it according to other scientists and was simply following a given protocol.

By the end of the course, Heather remarked: "I was never aware of inquiry teaching before. I only knew of hands-on learning but now I know that it's only part of the story. With inquiry teaching I can be a more effective teacher." She discussed how inquiry teaching involves students in more than just a hands-on experience. Students are able to explore and investigate having a larger role in the creation of the question or procedure to investigate. They would also be involved in critical thinking and the analyses of evidence that are primarily absent in simple confirmation activities. Her idea about the place and role of exploration in any lesson or unit also dramatically changed: "First I thought it was more like direct teaching and then they could run wild and observe and do all that stuff, but now it's more like letting them observe first and then discuss it afterwards." This new understanding was reflected in her post drawing of a science classroom in which she depicted five tables of four students in the middle of the class each serving as a station with various organisms and science equipments at each.

I love biology so I plan on having tons of animals in my class basically so the kids can explore them and enjoy. So I thought I'd have fish and a bunny or a hamster or something simple. And then have microscopes set up for some cells. And then have maybe another animal or an unknown animal that they have to classify. I would have plants by the window that they can grow and watch as they are growing. This would allow for constant and long term observations and explorations of things most kids find interesting.

One type of inquiry teaching approach that was emphasized in class was the $5 \mathrm{E}$ learning cycle model. Heather explained during her final interview and portfolio that she found the learning cycle to be a very effective method of employing inquiry teaching in the classroom. Whereas she had previously only considered hands-on activities as a critical part of science learning, she had since realized that there are other components that she had initially ignored. The learning cycle was mentioned at the end of the semester by Heather as a model that enables students to not only explore but also be engaged, involved in discussions, apply their knowledge, and be evaluated and assessed throughout the entire process.

This course and my experience teaching science this semester incorporated the entire cycle of engagement, exploration, explanation, elaboration, and evaluation. I found in applying this in 
constructing my lesson plans and final unit to be very effective in promoting and stimulating students' learning. The learning cycle reinforced the knowledge students were taking in and allowed for engaging them in the lesson. The elaboration allowed them to apply and further extend any information we had discussed. It proved to be very effective. Students were building the necessary connections.

She reiterated the importance of using the inquiry approach and her own special interest in utilizing the learning cycle model in order to "promote the best environment possible for students to learn and achieve their fullest potential." She continued:

I want my students to discover things for themselves and hope to provide them with all the necessary tools and motivation in reaching this goal. I hope to incorporate the learning cycle with all of my lessons, science and otherwise. The various stages ensure that the teacher is supporting students and allowing them to take an active role in the learning process. I want my students to actively take part in their learning.

Changes in her beliefs about learning had also led to modifications in her views of her roles as a teacher. Rather than thinking of herself as a director of students' learning, she had come to view herself as a facilitator instead. She explained how as a future teacher she would assist her students "in becoming successful learners in the science classroom by allowing the children to ask questions, research and explore the question, and find their own answers." She continued: "While this may not be possible at all times I would like to have my students work through problems and try to find solutions." She further explained how the students would be actively involved in each stage of the learning process with her serving as a facilitator of their learning. She no longer viewed herself as the source of information and director of learning.

By allowing the students to essentially be engaged, explore, discuss their learning, and so forth in an interactive environment, I believe they will become more interested, gain knowledge they find interesting, sort through problems inside and outside of class, and they will take more ownership of the material. My role would be to engage them, ask questions to drive their explorations and discussions, evaluate their learning and modify plans when necessary, and to create that learning environment to enrich their learning.

She discussed, extensively, the significance of assessing students' learning as part of her role as the facilitator. Her ideas for assessment included formative and summative assessment strategies that would encourage student reflection, enhance their learning, and provide her deeper insight into their learning and learning difficulties.

I hope to use science journals to assess where the students are in their understanding. I think by looking through their journals regularly and having them give presentations on the material they collected I will be able to gauge their understanding. I plan to use reflections, journals, projects, portfolios, and other creative methods that I have learned about to assess my students' knowledge.

Heather described the importance of making the classroom a "safe and comfortable" environment where students feel "comfortable in voicing their opinions, feelings, and questions" and confident in taking an active role in the classroom. She wanted to create a supportive, collaborative learning environment within the classroom that would foster not only the learning of content, but also important life lessons such as learning to work collaboratively with others. Heather continued to stress the significance of increasing students' interest and confidence in science. The teachers' role, she explained, was to make the science learning experience an active and interesting process for students, so they leave with a more positive attitude toward it. Furthermore, Heather emphasized the importance of preparing students to be comfortable with and yearning to continuously question and explore on their own.

I want them to use inquiry in my classroom and become comfortable with it. I want them to develop a desire to explore things from a scientific inquiry perspective, to ask questions, to test things, to make inferences, and develop their skills as a scientific learner. I want them to know that sometimes experiments and things involved in science don't always go as planned, but it's ok to keep trying.

Finally, having developed a more well-rounded understanding of science and science teaching, Heather also suggested integrating science and other school subjects in an effort to ensure allocating class time to science, which often tends to be ignored in the hype to prepare students in mathematics and literacy. The idea of integration had been a major component of the course and Heather had clearly become an advocate of the idea of integrating science with other subjects while at the same time acknowledging the distinction in the foci of these disciplines.

I believe all subjects can be linked. In the case of science, you can apply your math skills when working with formulas or measuring out quantities. Language arts can be incorporated when writing reflections, taking notes, or performing research. Literature is applied when reading on a topic or performing research. These are just a few examples showing how the various disciplines can all be linked together, specifically with science. 


\section{Attitude and Self-Efficacy}

Heather's experiences in the course had allowed her to view science and science teaching in a different light. These experiences and changes in her beliefs produced noticeable changes in her attitude and self-efficacy even though that was not apparent from her STEBI-B and Revised Attitude Toward Science scores, which remained virtually, unchanged (Table 2).

Table 2. Heather's Post Attitude and Self-Efficacy

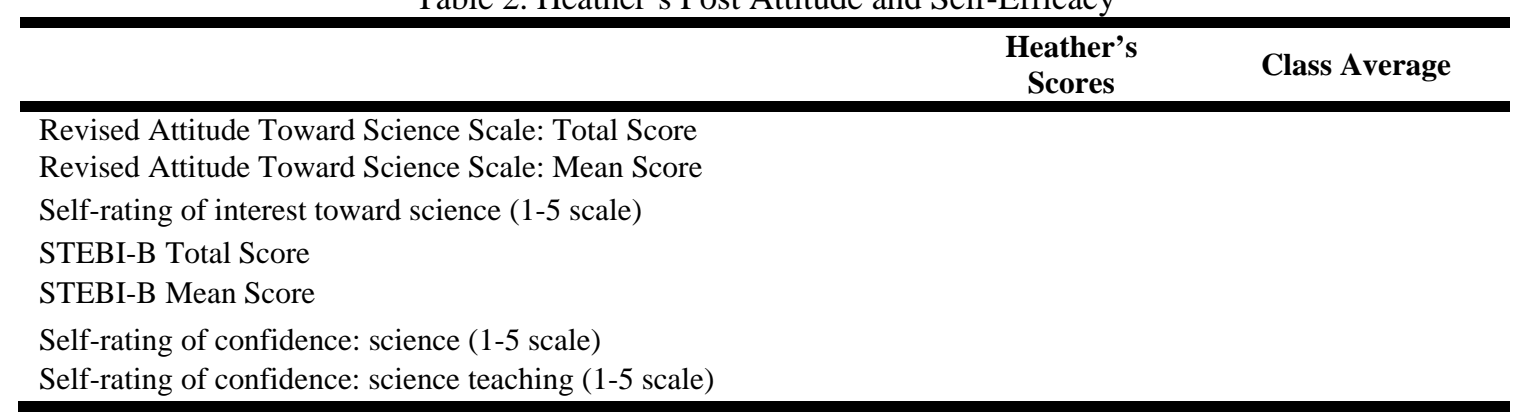

Her scores and self-ratings had already been high in the beginning of the semester, thus it was difficult, as she explained, "to raise them any further." Although not reflected in her scores, Heather repeatedly described how her attitude and self-efficacy, in particular toward teaching science, had indeed changed. Heather's attitude toward science had "peaked" even more and had she had become more determined in her passion about science as a result of the immersive and reflective nature of the course. The same held true for her attitude toward teaching science. Science remained her favorite subject to teach and she was even more resolute in her determination to teach science to the best of her abilities so to raise young children's enthusiasm for the subject. She added that her learning experiences in the methods course and the opportunity to develop inquiry-based lessons and observe the positive impacts on the children during the field experience had been instrumental in further augmenting her positive attitude toward teaching science.

I love watching students explore in an attempt to understand what is taking place. I enjoy the use of inquiry in a science lesson and find myself learning just as much about my students as they learn about a particular aspect of science. Observing the interactions and hearing the comments made by my students, this semester especially, has showed me how some students think and rationalize as they learn. My interest in teaching science had certainly increased even more than before the course.

Heather's confidence toward science remained high at the end of the course. She explained how she was further convinced and confident of her abilities in learning science and participating in scientific inquiry. Interestingly, her rating of her confidence in teaching science at the end of the semester was an 8.5 on a 1-10 scale. Her responses on the post interview and final teaching portfolio were quite revealing. Upon reflecting on her experiences throughout the semester, Heather indicated having initially overestimated her confidence in teaching science. She suggested that one reason for this overestimation was her lack of understanding about what teaching science should actually entail. She also explained how she had inaccurately equated her strength and ability in learning science to an equivalent strength and ability in teaching the subject. She alluded to her newly gained understanding of effective science instructional approaches and children's learning.

I know that I have the ability to learn science no matter what area of science; I have been able to teach myself many scientific ideas and know that I will be able to continue to do so in the years to come. Teaching science is a different topic though. I had indicated earlier that I thought I was very prepared; however, I now realize that was not entirely true. When I first started this class I thought teaching children science would be a piece of cake, but I have learned that this is not the case. Through this class I have learned so many things I was unaware of before and things that are necessary in effective science teaching. I learned, among other things, how to organize my lesson plans, what type of questions were best to ask, and how to lead activities that focus on inquiry learning. I had assumed that my interests would transfer over to the students, but I learned in this class that while my fascination with science might help students it would not necessarily always make them love science or be successful in it.

The course had taught her more about herself. She realized that although possessing and displaying a positive attitude and sense of confidence toward learning science are essential in teaching science and increasing students' interest in the subject; they are not sufficient. She added that she would 
use her strength in learning science and her positive attitude toward the subject to help her students learn the subject more effectively, but would now be able to employ many of the numerous valuable teaching tools in order to make her teaching more successful.

Heather was also quick to mention that despite her high confidence rating she had realized that she has more to learn and her confidence level could be augmented even further with more time and practice.

I rated myself at an 8.5 because I know that I have many things to learn before I become a great teacher. I will also need to learn that just because I think a topic is easy to learn my students might not feel the same. Until I have learned to teach students in a manner they understand I will still be striving for my best. Teaching is going to take years to become great at. I will make mistakes. My only hope is that I will learn from them and walk away from them with a greater understanding of what it means to be a teacher.

\section{The Influence of Course Components on the Domains}

Heather identified a number of course components that were influential in shaping her beliefs, attitude, and self-efficacy with regard to science and science teaching (Table 3).

Table 3. Influential Course Components and Impact on Three Domains

Course

Components

\section{Immersion in}

inquiry-based

learning

Collaborative

Learning

Readings and

Videos about

Science Teaching

Journal Reflections

Developing and

Teaching

Instructional Units

\section{Sample Excerpt}

I must say that the activities we did in class served as the most memorable and beneficial for me. One particular experiment I can remember occurred very early on in the year. We were all in separate groups and rotated around every so often as there was a different activity at each station. The thing I really enjoyed about this was that we were put in the roles of our future students. I loved how we used scientific inquiry and demonstrated how students will use this to work through an experiment. For each station, many of the group members would come up with different interpretations of what could be done with the given materials. In some way, this stressed to me how the mind of each child is different. This is why it is important to make science learning a personal learning experience.

We were able to talk about topics we did not understand, how lessons went, or anything else we were having difficultly with. Through my peers I understood the concepts, gained confidence and learned that I was not the only one struggling through a lesson or a class, and in some way it made me feel okay about not being on top of everything. This also benefited my attitude, because it made me realize that I was going to school to learn and was not expected to have all the answers and that it was okay to have a lesson go badly. All of my experiences in the course were part of becoming a better teacher.

From these readings I have found that children learn science best through inquiry. By allowing the children to ask their own questions and try to find the answer gives them more ownership over what they are doing and leads to greater involvement and a feeling of achievement. We also read how different organizations, whether it was the NSTA or a similar organization, discussed and promoted the use of inquiry in the classroom.

We witnessed directly how inquiry stimulated students' thinking. The teacher was not telling them what to think or how to think. The students were evolving and coming up with the appropriate concepts and responses all on their own. The students in these videos were teaching themselves, each other, and the teacher. I watched as students took a project and made it their own. They seemed to have learned more material than they would have if the teacher was standing at the front and telling them what to do and ask. I have learned that in order to get students excited about science I need to take more of a backseat and observe how they use questions to find answers and facilitate their inquiry.

I'm not a big fan of writing but I mean they made me go back over what we had learned, so they did helped, especially at the end when I went over to see what I thought and how my ideas had changed. I became a believer in requiring written reflections. I was never quite sold on writing in "Science Journals" until I experienced the understanding I developed by reflecting on my own experiences. Without reflection, our lives can become a series of doing and getting done. To develop understanding, we need to think about what we did and what it means to us or what we learned from it.

I attempted to use inquiry in my lessons, allowing my students to explore in a static electricity activity. I found my students teaching me new ways to approach static electricity with the balloon activity. I simply gave them a balloon and aluminum can to explore. The students successfully explained what was occurring and how you could move the aluminum can with the help of the balloon and the static electricity that resulted. It was a wonderful experience and I feel the students were learning a great deal as well as teaching me.

Immersion in inquiry-based learning 
The course engaged students in first-hand experience of science inquiry by immersing them in the process of active exploration of concepts and construction of new knowledge. The active engagement not only allowed her to participate and think from a student's perspective, but to also reflect on them from a teacher's point of view. Through such experiences she was further convinced of the importance inquiry-based learning in which students actively explore and discuss ideas. Heather also found this immersive experience effective in influencing her science and science teaching attitude, confidence, and beliefs.

\section{Collaborative Learning}

Heather viewed her peers and collaborative teamwork as imperative to her learning and development as a teacher. She discussed the importance of her peers in helping her gain further confidence with science. She explained how collaboration had allowed her to think everything through together and also to see everyone struggling and learning in the process. She expressed similar ideas about the benefits of collaborating with her peers during the development of their mini units, which enabled her to “understand that science isn't just about light bulbs and ice cubes, it is about working together and using one an others' ideas to work through problems.” She also found the class discussions quite beneficial in learning about other people's ideas and experiences. The presentations and the microteaching allowed her to become familiar with other people's ideas and lessons as well as effective classroom management or questioning techniques that some may have employed in their lessons that were missing in others. She was able to adopt and incorporate some of these effective ideas into her own unit or remember them for the future.

\section{Readings and videos of classroom teaching}

Heather found the course readings and videos valuable components of the course. She mentioned the case studies as particularly useful in allowing her to analyze a classroom situation and become more aware of the significance of constantly reflecting on one's teaching. Furthermore, the readings, some of which included practitioner articles, further convinced Heather of the importance of inquiry-based science teaching, especially as advocated by major science education organizations and reforms.

Heather explained how the series of videos they watched depicting inquiry-centered science classrooms had played a major role in convincing her of the effectiveness of the approach as a tool to teach science, because she was able to see its effectiveness in an actual classroom.

\section{Journal reflections}

Heather described herself as one who was not too interested in writing journals, because of her lack of interest and comfort with writing. However, even though she started the semester with minimal interest in doing the reflections, she grew to like them and especially realized its value in evaluating her growth over the span of the semester. She also found that it was a useful tool in communicating concerns and questions and receiving feedback and suggestions from the instructor.

\section{Developing and teaching instructional units}

Heather discussed the effectiveness of the learning cycle as a model which would allow her to include many important components of inquiry learning such as engaging students' interest, gauging their prior knowledge, allowing them the opportunity to explore, discussion of their observations or concepts, application of their understanding to new scenarios, and the ongoing evaluation of students' learning. Heather also discussed the importance of creating the unit plans and the discussion and peer critiquing that accompanied it. She was fond of the coherent nature of the science lessons that were created as a unit rather than as separate lessons. The experience of teaching in the field had also informed her of the importance of planning ahead but also being flexible enough to adapt to the situation and change plans if necessary. She described how teaching her inquiry-based mini-unit during field experience had allowed her to witness her students learning from the lesson and exploring and discussing points she had not anticipated. Heather also discussed the importance of receiving feedback from the instructor and her peers during the presentation of the mini-units and the final portfolio units.

\section{Conclusion}

This qualitative case study revealed a number of themes with respect to Heather's experiences, beliefs, attitude, and self-efficacy, both prior to and upon completion of the course. In doing so, it not only shed light on our understanding of this particular population of PSTs, but also allowed for certain assertions about teacher beliefs, attitudes, and self-efficacy, to be examined and further scrutinized. Prior research links positive attitude and self-efficacy to positive school science experiences and other 
external factors. However, this case study suggests that there may be some PSTs, such as Heather, whose interest about science may be more intrinsic in nature, although being given the opportunity to continue asking questions and researching on her own, rather than simply following her classrooms' activities helped keep Heather motivated, interested, and confident.

An interesting theme, which has not been addressed in prior research on pre-service teachers' science teaching self-efficacy, emerged in this study. Heather had initially attributed her high confidence in teaching science to her high confidence in learning science and high interest and positive attitude toward science. By the end of the course, Heather had recognized that she had initially overestimated her confidence level in teaching science because she had felt that if she were confident with learning science she was equally confident with teaching it. Throughout the course, she had realized her lack of understanding and weaknesses in teaching science and learned that possessing a positive attitude is not sufficient to be able to teach science. Had only a quantitative approach been utilized in the form of surveys and self-reports, such insight into Heather's thinking and changing attitude and self-efficacy as a result of the course would not have been possible.

A number of studies have indicated a link between in-service teachers' self-efficacy and teaching practices. However, Heather's case study suggests that, this may not necessarily be true in the case of PSTs who have little or no prior teacher preparation or experience. With this population, possessing a high science teaching self-efficacy alone, as was the case with Heather early in the semester, is not sufficient to assume reform-based beliefs and teaching practices. It must be understood that possessing positive attitude toward science or its teaching may lead to more science instruction but not necessarily effective science teaching. Prospective teachers who may have positive attitude toward science may simply do more science in their classrooms, as has been suggested by prior studies, however, their beliefs about teaching and learning science may be not aligned with reform philosophy and they may actually utilize ineffective teaching methods. In some situations, individuals could have a high science teaching self-efficacy because they have either (a) had positive prior science learning experience, (b) a high science learning self-efficacy, (c) positive attitude toward learning science, and/or (d) positive prior experiences teaching or working with children that make them believe they can also effectively teach science. However, as witnessed in the case of Heather, this high sense of self-efficacy might not always translate into effective teaching or reform-based beliefs if PSTs have not had prior experiences or training to help shape their beliefs and practices.

This underscores the importance of not simply clumping all PSTs into one large group when exploring changes in their affective and cognitive features. Each individual PST enters the program with various prior experiences and beliefs that will influence their self-efficacy and attitude and any changes they undergo throughout various programs or courses. We should make the effort to understand what prior experiences PSTs have had, what types of experiences they have as part of the course, the types of changes they go through, and the various factors that might influence them differently.

Furthermore, prior studies have often focused on these three domains separately or at best examined the relationship between any two of these features. This study was unique in that it concurrently explored the relationship between the constructs before and after the course. Initially, Heather's attitude toward science and science teaching as well as her self-efficacy toward science and science teaching were closely interrelated and a product of her own intrinsic interest in science and the types of experiences she was able to have during K-12. Her epistemological beliefs appeared to have been shaped by both her actual science experiences and what she had witnessed in the classrooms. This resulted in a concoction of ideas about science and science teaching, which were either not aligned with or indicative of an incomplete understanding of what is involved in learning and teaching science. At the end of the course, Heather's experiences had shaped her beliefs about science and science teaching, which consequently altered her own internal ideas about her attitude and confidence with regard to science and science teaching.

Finally, the results of this study, stress the importance of focusing our research and practice on all three domains concurrently. It is essential to recognize that three constructs do not operate in isolation and should not dealt with in isolation. They are interlinked and influence one another and ultimately PSTs' science teaching practices; therefore, attempts to imporve one without focusing on the other features will not result in enduring changes in practice. As educators, understanding the interrelationship between all three domains and PSTs' prior, as well as, course experiences will be an essential component in our success in improving our students' affective and cognitive features and their consequent teaching practices. 
